\title{
Disuse induced by the spine rectification vest: experimental study
}

\author{
Desuso gerado por colete de retificação de coluna: estudo experimental \\ Desuso generado por el corsé de rectificación de la columna: estudio experimenta \\ Rinaldo Roberto de Jesus Guirro', Eder João Arruda², Carlos Alberto da Silva²
}

\begin{abstract}
I The spine is the main support and movement axis of the locomotor system, and numberless clinical conditions may require that this structure be submitted to functional restriction. Among the non-invasive treatments used in spinal or appendicular skeleton injuries, the immobilization of the spine is used as a rehabilitation strategy. Because of the functional restrictions generated by restraining devices used on the spine, the proposal of this study was to adapt a spinal orthosis on rats, thus mimicking the immobilization of corrective vests and assessing the energetic conditions of thoracic muscles after 12 weeks of application. Wistar rats that were 42 days old were used in this study (post-weaning period), followed-up for 12 weeks in 2 groups called control (C) and rectification vests (R), which were made of PVC to immobilize the spine. The following concentrations were evaluated: glycogen (GLY) of the paravertebral muscle and the thorax; total proteins and DNA (TP/DNA) and interleukin-6 (IL-6). The normality Kolmogorov-Smirnov test was used for statistical analysis, followed by the Tukey test. A 5\% level was established for all of the calculations. It was observed that group R presented 12\% less body mass and GLY stores 21\% lower; the ratio between TP/DNA was in average 6.6\% lower; IL-6 concentrations were in average $25 \%$ higher. The study shows that the movement restriction in the spine leads to energetic crisis and compromised muscular development. More studies should be conducted with this model to generate physical therapy strategies that could reduce muscle compromise after spine immobilization.
\end{abstract}

Keywords I Musculoskeletal System; Immobilization; Spine
RESUMO I A coluna vertebral configura-se como o principal eixo de sustentação e movimentação do aparelho locomotor, sendo que inúmeras condições clínicas podem requerer que essa estrutura seja submetida à restrição funcional. Dentre os tratamentos não invasivos usados em lesões da coluna ou esqueleto apendicular, tem-se a imobilização da coluna enquanto estratégia de reabilitação. Frente às restrições funcionais geradas por dispositivos de contenção aplicados na coluna vertebral, a proposta desse estudo foi adaptar uma órtese na coluna de ratos, mimetizando a imobilização dos coletes corretivos e avaliar as condições energéticas dos músculos da caixa torácica após 12 semanas de aplicação. Foram utilizados ratos Wistar com 42 dias de vida (período pós-desmame), acompanhados por 12 semanas em 2 grupos denominados controle (C) e usuário de colete de retificação (R) confeccionado de PVC para imobilizar a coluna vertebral. Foram avaliadas as seguintes concentrações: glicogênio (GLI) da musculatura paravertebral e da caixa torácica; proteínas totais e DNA (PT/DNA) e interleucina 6 (IL-6). $\mathrm{Na}$ análise estatística foi utilizado o teste de normalidade Kolmogorov-Smirnov seguido do teste de Tukey. Em todos os cálculos foi fixado um nível crítico de 5\%. Foi verificado que o grupo R apresentou 12\% menos massa corporal e reservas de GLI em média 21\% menores; a relação PT/DNA apresentou-se em média 6,6\% menor; já as concentrações de IL-6 mostraram-se em média 25\% maiores. O estudo mostra que a restrição de movimento da coluna vertebral promove crise energética e comprometimento no desenvolvimento muscular. Sugere-se que sejam realizados

Study conducted at the Universidade Metodista de Piracicaba (UNIMEP) - Piracicaba (SP), Brazil.

'Biomechanics, Medicine and Rehabilitation Departament of the Locomotor System of the Medical School of Ribeirão Preto (USP) -

Ribeirão Preto (SP), Brazil.

2Postgraduate Program in Physical Therapy at Universidade Metodista de Piracicaba (UNIMEP) - Piracicaba (SP), Brazil.

\footnotetext{
Correspondence to: Carlos Alberto da Silva - Universidade Metodista de Piracicaba - Faculdade de Ciências da Saúde - Programa de Pós-graduação em Fisioterapia Correspondence to: Carlos Alberto da Silva - Universidade Metodista de Piracicaba - Faculdade de Ciências da Saúde
Rodovia do Açúcar, Km 156 - Campus Taquaral - CEP: 13400-901 - Piracicaba (SP), Brasil - E-mail: casilva@unimep.br

Presentation: Feb. 2013 - Accepted for publication: Feb. 2014 - Financing source: none - Conflict of interests: nothing to declare - Approval at the Animal Experimentation Ethics Committee n. 024/2006 (addendum 2009).
} 
outros estudos, com este modelo, para gerar estratégias de ação fisioterapêutica que possam reduzir o comprometimento muscular quando da imobilização da coluna.

Descritores I Sistema Musculoesquelético; Imobilização; Coluna Vertebral.

RESUMEN I La columna se presenta como el principal eje de sustentación y movimiento del sistema locomotor, siendo que innúmeras condiciones clínicas pueden requerir que esa estructura sea sometida a restricción funcional. Entre los tratamientos no invasivos usados en lesiones de la columna o esqueleto apendicular, se inmoviliza a la columna como una estrategia de rehabilitación. Frente a restricciones funcionales generadas por los dispositivos de contención aplicados en la columna vertebral, el propósito de este estudio fue adaptar un aparato ortopédico en la columna de ratones, imitando la inmovilización de los corsés ortopédicos y evaluar las condiciones energéticas de los músculos de la caja torácica después de 12 semanas de aplicación. Fueron utilizados ratones Wistar con 42 días de edad (período pos destete), seguidos por 12 semanas en 2 grupos llamados "control (C)" y “usuario de corsé de rectificación (R)” hechos de PVC para inmovilizar la columna vertebral. Fueron evaluadas las concentraciones de: glucógeno (GLY) de músculos paravertebrales y de la caja torácica; proteínas totales y ADN (PT/ADN) y interleucina 6 (IL-6). En el análisis estadístico se utilizó el test de normalidad de Kolmogorov-Smirnov seguido del test de Tukey. En todos los cálculos se estableció un nivel crítico de 5\%. Se verificó que el grupo R tuvo 12\% menos masa corporal y un promedio de $21 \%$ de reservas GLY más escasas; la relación PT/ ADN se mostró, en promedio, 6,6 \% más pequeña, mientras que las concentraciones de IL-6 en promedio, se mostraron $25 \%$ más grande. El estudio muestra que la restricción de movimiento de la columna promueve crisis energética y compromiso en el desarrollo muscular. Se sugiere que se lleven a cabo otros estudios, con este modelo, para generar estrategias de acción fisioterápica que puedan reducir la afectación de los músculos durante la inmovilización de la columna.

Palabras clave I Sistema Muscoesquelético; Inmovilización; Columna Vertebral.

\section{INTRODUCTION}

The spine is configured as an osteomioarticular, which forms the support and mobility axis of the locomotor system in a highly structured way. And because it presents this great functional structured composition, it is subjected to several forms of compromise, which can lead to permanent or temporary ${ }^{1}$ functional restriction.

Out of the most common conditions that lead to functional spinal restriction, there are: vertebral, rib, scapular and pelvic waste fractures, degenerative diseases, scoliosis, besides other forms of compromise that range in causal mechanisms and complexity and corroborate the restriction and consequent disuse or hypoactivity ${ }^{2-4}$.

Concerning static and dynamic spinal stability, this system is inherently stable, which requires an active muscle support for postural maintenance and changes ${ }^{3,5}$. Considering there is spinal static stability is ensured by different ligaments, besides intervertebral disks, the dynamic stability calls the attention, since it is ensured by intrinsic and extrinsic spinal muscles. This fact calls the attention to the different conditions that can lead to functional restriction of the spine, once the muscle tissue is considered to be the one with most plasticity in the human body $y^{6,7}$.

By understanding that the muscle tissue is highly adaptable to stimuli (or the lack of stimuli), any changes in the contracting dynamics of primary and secondary spinal motor muscles, directly, can reflect on functional changes, as the ones observed in cases of scoliosis, which present hypotonia, diffuse muscle weakness and varied pain intensity ${ }^{3,5}$. Studies that investigated scoliosis reported that the functional restriction in the spine has a direct impact on paravertebral and respiratory muscles, once these muscles are closely connected to trunk functionality ${ }^{6,8,9}$.

Considering that several conditions can lead to functional restriction induced by pathological states, or even as therapy, it is important to investigate the effects of this functional restriction focusing on the spine. In this sense, studies on animal models are not only necessary, but they also have always been very relevant from the methodological point of view, because this type of study offers more experimental control. It is important to mention the fact that scoliosis can manifest in quadrupeds, which reinforces the use and the need for studies with animals ${ }^{10-12}$.

Based on the different forms of functional restrictions that diseases and therapies submit to the spine, this study aimed at adapting a thoracic orthosis in rats, in order to mimic immobilization (functional restriction) of therapeutic vests, and at assessing energetic conditions, as well as the ratio between protein synthesis/degradation of trunk and thoracic muscles after 12 weeks of use. 


\section{METHODOLOGY}

It is an experimental study that used male 42-day old albino Wistar rats (post-weaning period), which were followed-up during 12 weeks. The animals weighed $90 \pm 10 \mathrm{~g}$ on the $1^{\text {st }}$ week and $230 \pm 10 \mathrm{~g}$ on the $12^{\text {th }}$ week (end) of the study. Animals $(n=12)$ were distributed in 2 groups, and separated into 4 boxes with 3 animals each. The control group (C) had 6 animals, and the group with rectification vests $(\mathrm{R})$ also had 6 animals. Animals were fed with ration and water ad libitum, and were submitted to a $12 \mathrm{~h}$ bright/ dark photoperiod cycle. Orthoses were placed on the $42^{\text {nd }}$ day of life, which is considered to be the postweaning period. Two researchers were necessary to place the vests, since the animals were not sedated or under anesthesia. From the $1^{\text {st }}$ to the $12^{\text {nd }}$ week of the study, orthoses were replaced by larger ones, and such a replacement aimed at accompanying animal's growth. The placement of the orthosis allowed the spine of the animal to be stabilized at a neutral position, which concerns movements of trunk flexion, extension and inclination. This stabilization at the neutral position was a result of the placement of a metallic connection rod between the anterior and the posterior band. Initially ( $1^{\text {st }}$ week), the placed device was $5 \mathrm{~cm}$ long, and every week this rod was approximately $3 \mathrm{~mm}$ longer. The used orthosis is made of PVC, and this material provides great flexibility for the adjustment of a scapular and a pelvic band (Figure 1), similarly to a model used in studies about scoliosis ${ }^{13}$. The differential of the model used in this study was the non-induction of curvature, as observed in Figure 1. Since this is a non-invasive methodology, there was no sampling loss during the whole experimental period. In order to follow-up weight development, animals were weighed weekly in Filizola ${ }^{\circledR}$ a semi-analytic scale. For sampling collection, rats were euthanized with sodium pentobarbital (50 mg/kg, i.p.), and samples of pectoral, paravertebral and intercostal muscles on the right and left sides were collected and immediately submitted to the biochemical evaluation of the glycogen content (sulfur phenol method ${ }^{14}$ ); to the concentration of total proteins (bi-uterus method) and DNA concentration (diphenylamine method). In order to determine the serum concentration of interleukin-6, the ELISA method was used, according to the specifications of the Kit (Biosource International) ${ }^{15}$.
The Shapiro-Wilk normality test was used in statistical analysis to verify data distribution. After nonnormality was observed, the non-parametric methodology was employed, and the Mann-Whitney test was used to analyze both groups. The $5 \%$ significance level was established in all calculations.

\section{RESULTS}

At first, the body mass curve of the animals was assessed. We observed that after 12 weeks, the group with the vest attached to their bodies (Group R) presented with mass $12 \%$ lower than the group without the orthosis (Group C) (Figure 2).

With regard to aspects indicating metabolism, glycogen stores were evaluated. In group $\mathrm{C}$, there were no differences between muscle stores on the right and left sides. On the other hand, group $\mathrm{R}$ presented lower glycogen stores $(28,18,21,31,20$ and $28 \%$, respectively, on the right and left pectoral muscles, right and left intercostal muscles, right and left paravertebral muscles), when compared to group C (Figure 3 ).

Afterwards, the ratio between total protein/muscle DNA was evaluated. In this case, it was possible to observe the following reduction in group $\mathrm{R}: 6$; 7; $7 ; 6 ; 8.5$ and $6 \%$, respectively to the right and left pectoral muscles, right and left intercostal muscles, right and left paravertebral muscles, when compared to group $\mathrm{C}$ (Table 1$)$.
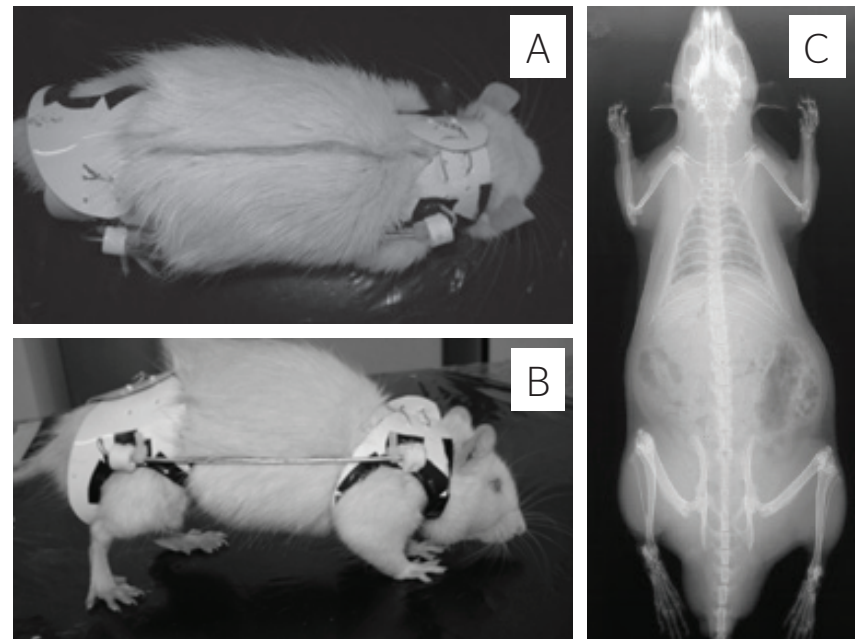

Figure 1. Upper (A) and lateral view (B) of the animal in the rectified group (R) during the use of orthosis and x-ray after a 12-week immobilization (C) 
Finally, the objective was to perform the molecular evaluation of the serum concentration of interleukin-6. This assessment revealed that group $\mathrm{R}$ presented values that were $25 \%$ higher $(200 \pm 12 \mathrm{pg} / \mathrm{mL}$ in group $\mathrm{C}$ and $250 \pm 10 \mathrm{pg} / \mathrm{mL}$ in group $\mathrm{R})$.

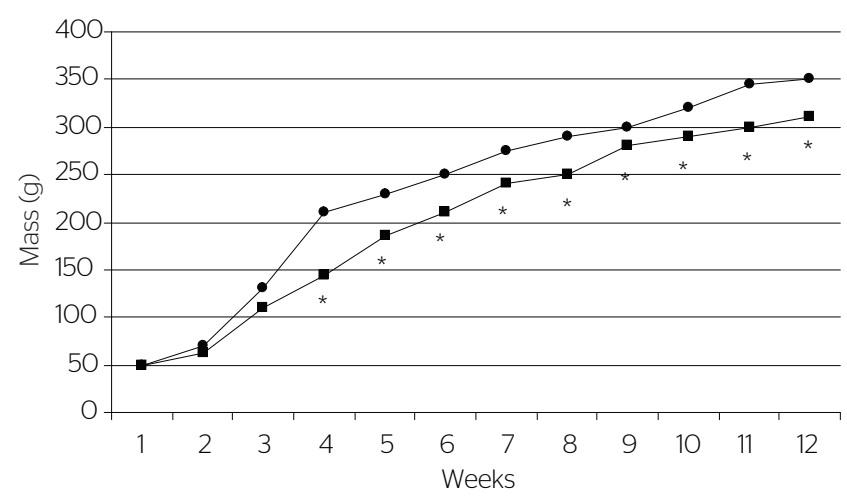

${ }^{*} p<0.05$ versus control

Figure 2. Mass (g) of the animals in the control $(\bullet)$ and rectified groups ( $\bullet$ ) during the 12 experimental weeks $(n=12)$

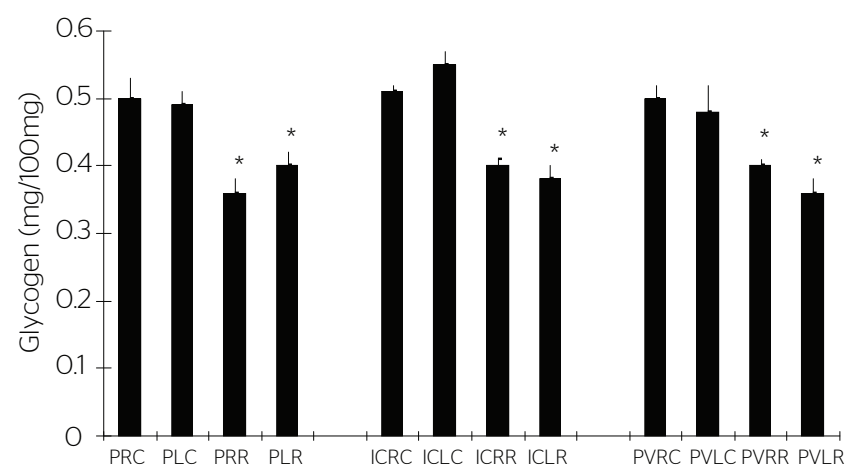

${ }^{*} \mathrm{p}<0.05$ to the respective control

Figure 3. Glycogen concentrations ( $\mathrm{mg} / 100 \mathrm{mg}$ ) of pectoral (P), intercostal (IC) and paravertebral (PV) muscles on the right (R) and left sides ( $L$ ) of control (C) and rectified animals ( $R$ )

Table 1. Ratio between total protein/DNA (mg/100 mg) of the control and rectified groups. $n=12$

\begin{tabular}{lll}
$\begin{array}{l}\text { Ratio between total protein/DNA } \\
(\mathrm{mg} / 100 \mathrm{mg})\end{array}$ & $\begin{array}{c}\text { Control } \\
\text { group (C) } \\
\text { Mean } \pm \mathrm{SD}\end{array}$ & $\begin{array}{c}\text { Rectified } \\
\text { group (R) } \\
\text { Mean } \pm \mathrm{SD}\end{array}$ \\
\hline Right pectoral & $3.28 \pm 0.03$ & $3.10 \pm 0.01^{*}$ \\
Left pectoral & $3.69 \pm 0.04$ & $3.43 \pm 0.02^{*}$ \\
Right intercostal & $3.45 \pm 0.02$ & $3.22 \pm 0.01^{*}$ \\
Left intercostal & $3.46 \pm 0.03$ & $3.27 \pm 0.02^{*}$ \\
Right paravertebral & $3.41 \pm 0.03$ & $3.12 \pm 0.04^{*}$ \\
Left paravertebral & $3.39 \pm 0.01$ & $3.18 \pm 0.03^{*}$ \\
*p<0.05 versus control & &
\end{tabular}

\section{DISCUSSION}

Literature presents some models of functional restriction of the spine in animals, mostly rats. However, it presents invasive methodologies that are difficult to perform, and this fact makes it difficult to standardize the analyses ${ }^{10-12}$. In this study, a non-invasive model of spinal restriction was employed, which was considered to be easy and was based on the study y Silva et al. ${ }^{13}$. The difference is that, in this study, the animal's spine was not inclined to any side, since the objective was to assess the effects of functional restriction at the neutral position of the spine.

The 12-week time of contention used in this study was based on the classic study by Sarwak et al. ${ }^{16}$, who analyzed scoliosis among rats and mentioned that, on the $12^{\text {th }}$ week of the study, the curvature does not recedes after induction. In the same direction, Silva et $a .^{13,17}$ studied the 12 -week time of scoliosis induction among rats, and such an induction was performed by means of a functional restriction similar to the one used in this study. Therefore, there are two functional restriction methodologies (invasive and non-invasive) that worked on a 12-week time, and this fact was the temporal base of this study.

The functional restriction model (contention by orthosis) used in this study showed important changes. Concerning body mass, it was observed that the group that used the device $(\mathrm{R})$ developed less. It is important to point out that this behavior is not related to loss, since the animals who had the orthosis presented this lower mass pattern during the whole experimental period.

It is assumed that the body mass behavior may be a result of changes in the gastroenteric tract or in the modulation of regulating functions of the processes involved in absorption - by considering that the posterior side of the device pressures the abdominal region, once this is a regulating band system. In this sense, it is known that in situations where intestinal processes of absorption and excretion are influenced, there may be a reflex on body mass ${ }^{18}$.

The energetic balance of the skeletal musculature depends on the integrity of capture and metabolization processes of energetic substrates, especially glucose, as well as on the integrity of the population of insulin receptors, which modulates both the formation of stores and hexose metabolism. In this context, it is common sense that the functional efficiency of the muscles is deeply related to glycogen content, and 
such storage reaches the minimum values when the muscle is fatigues ${ }^{19}$. Therefore, hypoactivity, functional restriction or disuse also leads to reduced signaling mechanisms that are in charge of the maintenance of increase in energetic stores, which are essential to maintain posture ${ }^{20,21}$.

Disuse is target of studies performed in several clinical conditions, such as: long bedside periods, fixation of limbs, microgravity or the use of orthosis, and these factors trigger the catabolic state of skeletal muscles ${ }^{22,23}$. Molecular studies performed in skeletal muscles submitted to disuse verified reduced insulin transduction signaling, thus suggesting deficit in the activation of the insulin receptor and of the enzymes activated from it, including the phosphorylation of IRS-1 (insulin receptor substrate 1), activation of $\mathrm{P} 13-\mathrm{K}$, decreased population of GLUT4 transporters and implantation of the picture of resistance to insulin ${ }^{24,13}$.

Based on the exposed, the results in this study show expressive reduction in muscle glycogen stores, mimicking the disuse condition generated by other immobilization methods.

According to Halar and Kathleen ${ }^{25}$, muscle weakness resulting from disuse is a consequence of depleted levels of glycogen store, reduced sarcomeres in series, reduced strength and resistance to fatigue resulting from atrophy of fibers I and II and decreased function. From the data presented herein, it is possible to suggest that orthosis promotes disuse by compromising the homeostasis of the contracting process of the muscles placed between the axillary and pelvic bands, which could explain the reduced ratio between total protein/DNA.

The increase in serum IL-6 may have a direct relation with muscle injury or reduced energetic store ${ }^{26}$. From this perspective, it is possible to suggest that the disuse caused by orthosis may have promoted the catabolism by reducing and limiting the contracting capacity. It is also known that higher serum concentrations of IL-6 are related to more stress in muscle mechanics. This requires adjustments and adaptation in order to stimulate plasticity ${ }^{27}$, which may have occurred by the application of the orthosis, which mimicked the rectification vests.

Keller et al. ${ }^{28}$ demonstrated that human skeletal muscles activate the transcription of the IL-6 gene, while glycogen stores become low. In this sense, this study, this study reinforces this fact, since reduced glycogen stores were observed in muscles exposed to rectification orthosis.

Finally, Pedersen et al. ${ }^{29}$ suggested that interleukin- 6 is produced separately by the skeletal muscle and secreted in major proportions in the bloodstream. This suggests that IL-6 may play an important role for the maintenance of energetic homeostasis, once, inside its range of action, it induces lipolysis and glycogenolysis, adjusting the availability of substrates according to the need.

It is important to emphasize that, regardless of structural benefits provided by rectification vests, there is an energetic crisis in trunk muscles, which is represented by low glycogen stores and limited structural development, as presented by the lower mass in the group submitted to restriction. The findings in this study show that functional restriction caused by rectification vests can be an important inducer of muscle weakness, which can interfere in therapeutic processes in which functional restrictional is necessary.

\section{CONCLUSION}

The study shows that the functional restriction of the spine in an experimental condition led to reduced energetic stores of trunk muscles, and such a reduction was followed-up by the reduced ratio between total protein/DNA. It was also possible to observe the elevation of serum concentrations of interleukin-6, which is a mechanism that attempts to reverse protein catabolism in case of functional restriction.

Based on the methodological practicality presented by the restriction model used in this study, as well as on the observance of experimental studies that are based on the functional restriction of the spine by means of different methodologies, it is suggested that further studies be conducted in order to establish a lower methodological variation. Therefore, it would be possible to achieve better comparison parameters concerning structural changes that may compromise the spine in conditions of functional restriction.

\section{REFERENCES}

1. Morawietz C, Moffat F. Effects of locomotor training after incomplete spinal cord injury: a systematic review. Arch Phys Med Rehabil. 2013;94(11):2297-308.

2. Rahimi-Movaghar V, Sayyah MK, Akbari H, Khorramirouz R, Rasouli MR, Moradi-Lakeh M, et al. Epidemiology of traumatic spinal cord injuryin developing countries: a systematic review. Neuroepidemiol. 2013:41(2):65-85. 
3. Mordecai SC, Dabke HV. Efficacy of exercise therapy for the treatment of adolescent idiopathic scoliosis: a review of the literature. Eur Spine J. 2012;21(3):382-9

4. Kalff R, Ewald C, Waschke A, Gobisch L, Hope C. Degenerative lumbar spinal stenosis in older people: current treatment options. Dtsch Arztebl Int. 2013:110(37): 613-24.

5. Flück M. Functional, structural and molecular plasticity of mammalian skeletal muscle in response to exercise stimuli. J Exp Biol. 2006;209(Pt 12):2239-48.

6. Roso V, Bitu S de O, Zanoteli E, Beteta JT, de Castro RC, Fernandes AC. Surgical treatment of scoliosis in spinal muscular atrophy. Arq Neuropsiquiatr. 2003;61(3A):631-8.

7. Haig AJ, London Z, Sandella DE. Symmetry of paraspinal muscle denervation in clinical lumbar spinal stenosis: support for a hypothesis of posterior primary ramus stretching? Muscle Nerve. 2013;48(2):198-203.

8. Tangsrud SE, Carlsen KC, Lund-Petersen I, Carlsen KH. Lung function measurements in young children with spinal muscle atrophy; a cross sectional survey on the effect of position and bracing. Arch Dis Child. 2001;84(6):521-4.

9. Posadzki P, Ernst E. Spinal manipulation: an update of a systematic review of systematic reviews. N Z Med J. 2011;124(1340):55-71.

10. Ouellet J, Odent T. Animal models for scoliosis research: state of the art, current concepts and future perspective applications. Eur Spine J. 2013;22(Suppl 2):S81-95

11. Gorman KF, Brenden F. Idiopathic-type scoliosis is not exclusive to bipedalism. Med Hypotheses. 2009;72(3):348-52.

12. Jansen MM, de Wilde RF, Kouwenhoven JW, Castelein RM. Experimental animal models in scoliosis research: a review of the literature. Spine J. 2011;11(4):347-58.

13. Silva CA, Guirro RR, Delfino GB, Arruda EJ. Proposal of non-invasive experimental model to induce scoliosis in rats. Rev Bras Fisioter. 2012;16(3):254-60.

14. Lo S, Russell JC, Taylor AW. Determination of glycogen in small tissue samples. J Appl Physiol. 1970;28(2):234-6.

15. Nishiyama A, Cavaglieri CR, Curi R, Calder PC. Arachidonic acidcontaining phosphatidylcholine inhibits Iymphocyte proliferation and decreases interleukin-2 and interferon-g production from Concanavalin A-stimulated rat Iymphocytes. Biochim Biophys Acta. 2000;1487(1):50-60
16. Sarwark JF, Dabney KW, Salzman SK, Wakabayashi T, Kitadai HK, Beauchamp JT, et al. Experimental scoliosis in the rat. I. Methodology, anatomic features and neurologic characterization. Spine (Phila Pa 1976). 1988;13(5):466-71

17. Silva CA, Guirro RRJ, Fonseca W, Arruda EJ, Grasso DO. Assessment of rat behavior with induced scoliosis by polyvinil choride vest. J Chin Clinic Med. 2008;3(11):621-6.

18. Tsuchida T, Fukuda S, Aoyama H, Taniuchi N, Ishihara T, Ohashi N, et al. MGAT2 deficiency ameliorates high-fat diet-induced obesity and insulin resistance by inhibiting intestinal fat absorption in mice. Lipids Health Dis. 2012;14:11-75.

19. Hargreaves M. Muscle glycogen and metabolic regulation. Proc Nutr Soc. 2004;63(2):217-20

20. Allen DG, Lamb GD, Westerblad H. Skeletal muscle fatigue: cellular mechanisms. Physiol Rev. 2008:88(1):287-332.

21. Ortenblad N, Nielsen J, Saltin B, Holmberg HC. Role of glycogen availability in sarcoplasmic reticulum Ca2+ kinetics in human skeletal muscle. J Physiol. 2011;589(Pt 3):711-25.

22. Jackman RW, Kandarian SC. The molecular basis of skeletal muscle atrophy. Am J Physiol Cell Physiol. 2004:287(4):C834-43.

23. Silva CA, Petermann C, Cancelliero KM, Durigan JLQ, Polacow MLO. IGF-1 minimiza os efeitos deletérios do desuso no músculo sóleo de ratos. Acta Ortop Bras. 2011;19(3):137-40.

24. Durigan JLQ, Cancelliero KM, Bossi PL, Delfino GB, Montebello MIL, Guirro RRJ, et al. Metabolic and morphometric alterations inherent to neuromuscular electric stimulation in the antagonist muscle submitted to ankle joint immobilization. Braz Arch Biol Technol. 2009;52(1):85-91.

25. Halar EM, Kathleen RB. Imobilidade. In: De Lisa JA. Tratado de Medicina e Reabilitação: Princípios e práticas. 2 ed. São Paulo: Manole; 2002. v. 2, p.1067-87.

26. Prestes J, Donato FF, Frolinni AB, Cavaglieri CR. Papel da interleucinas-6 como sinalizador em diferentes tecidos durante o exercício físico. Fit Perf J. 2006:5(6):348-53.

27. Suzuki K, Nakaji S, Yamada M, Liu Q, Kurakake S, Okamura N, et al. Impact of a competitive marathon race on systemic cytokine and neutrophil responses. Med Sci Sports Exerc. 2003; 35(2):348-55.

28. Keller C, Steensberg A, Pilegaard H, Osada T, Saltin B, Pedersen BK, et al. Transcriptional activation of the IL-6 gene in human contracting skeletal muscle: influence of muscle glycogen content. FASEB J.2001;15(14):2748-50.

29. Pedersen BK, Steenberg A, Schjerling P. Muscle-derived interleukin-6: possible biological effects. J Physiol. 2001;536(Pt 2):329-37. 